http://jmscr.igmpublication.org/home/ ISSN (e)-2347-176x ISSN (p) 2455-0450 crossref DOI: https://dx.doi.org/10.18535/jmscr/v8i9.32

\author{
Journal Of Medical Science And Clinical Research \\ IGM Publication \\ An official Publication of IGM Publication
}

\title{
Treatment Management by following Hematological Tips in a Postpartum Case Infected with COVID-19
}

\author{
Authors \\ Vildan Gursoy' ${ }^{1}$, Suna Avci ${ }^{2}$, Selime Ermurat ${ }^{3}$ \\ ${ }^{1}$ Department of Hematology, Bursa Yuksek Ihtisas Education and Training Hospital, University of Health \\ Sciences, Bursa, Turkey \\ ${ }^{2}$ Department of Geriatrics, Bursa Yuksek Ihtisas Education and Training Hospital, University of Health \\ Sciences, Bursa, Turkey \\ ${ }^{3}$ Department of Rheumatology, Bursa Yuksek Ihtisas Education and Training Hospital, University of Health \\ Sciences, Bursa, Turkey
}

\begin{abstract}
Much is unknown about COVID-19 and its effects. The findings reported here aim to emphasize the clinical features of COVID-19 infection in pregnant women, the treatment process in the postpartum period, the presence of co-infection, and the value of hematological parameters in the management of the treatment.
\end{abstract}

\section{Introduction}

Coronavirus Disease 2019 (COVID-19) is a novel viral disease with person-to-person transmission that has spread many other countries worldwide since the end of $2019^{(1-5)}$. The World Health Organization (WHO) characterized the COVID19 outbreak as a pandemic on March 11, 2020 when the number of cases of COVID-19 outside China increased 13-fold ${ }^{(6)}$. Over a few months, COVID-19 has spread rapidly, with more than 8 million confirmed cases on June 15, 2020. COVID-19 is a systemic infection with clinical manifestations mainly included fatigue, fever, non-productive cough, dyspnea and a significant impact on the hematopoietic system ${ }^{(7,8)}$. Patients' laboratory examinations included lymphocyte, platelet and hemoglobin count dynamics, and inflammatory indices; lactate dehydrogenase (LDH), C-reactive protein (CRP), ferritin, fibrinogen and D-dimers may help to identify cases with a dismal prognosis and prompt intervention to improve outcomes ${ }^{(9)}$. The clinical manifestations and laboratory symptoms are similar to other viral infections and systemic inflammatory conditions. Therefore, the differential diagnosis is required. Herein, we report a postpartum case of infected with COVID19 in which the first clinical symptoms were related to disease progression. However, in ongoing clinical follow-up, it was noticed that the only cause was not COVID-19. Based on abnormalities in hematological parameters, she was successfully treated as a result of a multidisciplinary approach.

\section{Case Report}

A 35-year-old woman at 34 weeks of pregnancy suffering shortness of breath, weakness and sore 
throat was referred to our hospital. The patient had no known underlying disease and declared no specific issue in her medication and family history. She noted no contact with anyone diagnosed with COVID-19, as well as no recent travel history. All the previous pregnancy scheduled screening tests were performed to the date and all were normal. Early examinations showed respiratory rate $(R R)=20 / \mathrm{min}$, heart rate $(\mathrm{HR})=110 / \mathrm{min}$, body temperature $(\mathrm{BT})=37$, $2^{\circ} \mathrm{C}$, blood pressure $(\mathrm{BP})=150 / 110 \mathrm{mmHg}, \mathrm{O} 2$ saturation $=98 \%$. Laboratory results were white blood cell (WBC): $11.8310^{3} / \mathrm{mL}$, neutrophil (neu): $9.3710^{3} / \mathrm{mL}$, lymphocyte (lymph): $1.9610^{3} / \mathrm{mL}$, hemoglobin (hgb): $4,5 \mathrm{~g} / \mathrm{dL}$, platelet (plt): 45 $10^{3} / \mathrm{mL}$, creatinine (cre): $0,98 \mathrm{mg} / \mathrm{dl}$, aspartate transaminase (AST):136 U/L, alanine transaminase (ALT): $77 \mathrm{U} / \mathrm{L}, \mathrm{LDH}: 2434 \mathrm{U} / \mathrm{L}$, total bilirubin: 1,22 $\mathrm{mg} / \mathrm{dl}$, direct bilirubin: 0,61 $m g / d l$. A pharyngeal swab sample for COVID-19 was taken in the emergency room and hospitalized in the obstetrics clinic. She was delivered by cesarean because of preeclampsia and fetal distress. On the postoperative day 1, the patient's COV-2 PCR test was reported positive. In blood tests, CRP: $90,3 \mu \mathrm{g} / \mathrm{mL}$, D-dimers: $10,12 \mu \mathrm{g} / \mathrm{mL}$, ferritin: $44 \mathrm{ng} / \mathrm{mL}$, fibrinogen: 438 were detected. She was moved to the pandemic service for the follow-up. A computed tomography (CT) scan was performed. According to the published data, the findings were not completely in concordance with COVID-19. Hydroxychloroquine on the 1st day, 2x400 mg loading, 2x200 mg maintenance and oseltamivir $2 \times 75 \mathrm{mg}$ were started. Enoxaparin $0.4 \mathrm{mg}$ subcutan $1 \times 1$ was also applied. The second COV-2 PCR test also resulted positively. A full laboratory test was requested, which most importantly showed leukopenia, deep anemia and thrombocytopenia accompanied by elevated CRP, procalcitonin, ferritin and LDH levels. The patient whose deep anemia and thrombocytopenia continued despite transfusion and treatment was consulted to hematology. Direct, indirect coombs were negative, $\mathrm{LDH}$ was high, bilirubin values were normal, triglyceride was higher than normal.
Transferrin saturation was below $10 \%$. It was recommended to perform peripheral blood smear, revision of infection treatment and to administer platelet and erythrocyte suspension if necessary. Thorax CT of the patient was repeated on the 10th day of treatment and bilateral infiltration compatible with COVID-19 was observed. CRP was $326 \mathrm{mg} L$, Procalcitonin $2.18 \mathrm{ng} / \mathrm{mL}$, ferritin $2332 \mathrm{ng} / \mathrm{mL}$, lymph: $0.6710^{3} / \mathrm{mL}$, hgb: $7.6 \mathrm{~g} / \mathrm{dL}$, plt: $2310^{3} / \mathrm{mL}$. On the 1 st day, $2 \times 1600 \mathrm{mg}$ loading and then $2 \times 600 \mathrm{mg}$ maintenance favipiravir treatment started. However, on the third day of favipiravir treatment, the patient's progression continued in her laboratory findings. Despite the treatment, progression was observed, but the patient did not need intensive care. In peripheral smear, $78 \%$ neutrophils, $20 \%$ lymphocytes and $2 \%$ monocytes were observed. Atypical character cells and blastic cells were not detected. No significant increase in the number of fragmented erythrocytes or schistocytes was observed. There were grade 3 toxic granulation, vaculations and occasional hypersegmentation in the granulocytic series. Hematological findings were thought to be related to infection. Due to the presence of a disease-related progression in the COVID-19infected patient and a recent history of surgery, surgical site infections were considered. The patient was thought to be going to hemophagocytic syndrome due to infectious processes. It was suggested to switch to more aggressive treatment options. The patient was evaluated using the multidisciplinary approach by the departments of infectious diseases, internal medicine, obstetrics, hematology and rheumatology. The patient was re-evaluated for the focus of infection. After a detailed physical examination, hyperemia, opening at the wound site and purulent discharge were observed in the cesarean line. We should note that the patient was a Syrian refugee and did not speak Turkish. Thus, she never complained of the lesion because she could not express herself and was afraid of religious concerns. Imipenem $4 \times 500 \mathrm{mg}$ and teicoplanin 2x400 mg loading, 1x400 mg 


\section{JMSCR Vol||08||Issue||09||Page 173-177||September}

maintenance treatment was started due to surgical site infection. Despite favipiravir treatment, the patient's deep anemia and thrombocytopenia continued. Acute phase reactants increased. Tocilizumab treatment was also started. Abdominal tomography was performed to evaluate the presence of the abscess. A lesion with a cystic heterogeneous structure with intraperitoneal extension in its widest part measuring $18 \times 6 \mathrm{~mm}$ and the longitudinal length of
$17 \mathrm{~cm}$ was observed. Surgical debridement and wound suturing were performed for wound infection by taking appropriate protection measures in COVID-19 positive patients by obstetric gynecology. The patient underwent secondary suturing and evacuation of the hematoma inside the rectus. The last COV-2 PCR test also resulted in negative. Postoperative on the 5 th day, she was discharged with health to meet with her baby.

Table 1 Clinical Laboratory Results through the first Postoperative Day

\begin{tabular}{|c|c|c|c|c|c|c|c|c|c|c|c|c|c|c|c|}
\hline Measure & $\begin{array}{c}\text { Reference } \\
\text { Range }\end{array}$ & $\begin{array}{c}\text { Day } \\
1\end{array}$ & $\begin{array}{c}\text { Day } \\
2\end{array}$ & $\begin{array}{c}\text { Day } \\
\mathbf{3}\end{array}$ & $\begin{array}{c}\text { Day } \\
6\end{array}$ & $\begin{array}{c}\text { Day } \\
7\end{array}$ & $\begin{array}{c}\text { Day } \\
8\end{array}$ & $\begin{array}{c}\text { Day } \\
9\end{array}$ & $\begin{array}{c}\text { Day } \\
10\end{array}$ & $\begin{array}{c}\text { Day } \\
12\end{array}$ & $\begin{array}{c}\text { Day } \\
14\end{array}$ & $\begin{array}{c}\text { Day } \\
16\end{array}$ & $\begin{array}{c}\text { Day } \\
19\end{array}$ & $\begin{array}{c}\text { Day } \\
24\end{array}$ & $\begin{array}{c}\text { Day } \\
31\end{array}$ \\
\hline $\begin{array}{l}\text { White blood cell } \\
\text { count }\left(10^{3} / \mathrm{mL}\right)\end{array}$ & $3.5-10.5$ & 9.27 & 8.3 & 7.12 & 3.95 & 3.91 & 3.77 & 3.46 & 4.54 & 3.27 & 2.59 & 2.75 & 3.65 & 3.62 & 4.21 \\
\hline $\begin{array}{l}\text { Neutrophil count } \\
\left(10^{3} / \mathrm{mL}\right)\end{array}$ & $1.9-8$ & 7.29 & 6.7 & 5.6 & 3.18 & 2.89 & 2.76 & 2.56 & 3.66 & 2.12 & 2.09 & 1.55 & 2.06 & 2.14 & 2.2 \\
\hline $\begin{array}{l}\text { Lymphocyte count } \\
\left(10^{3} / \mathrm{mL}\right)\end{array}$ & $0.9-2.9$ & 1.75 & 0.89 & 0.74 & 0.66 & 0.85 & 0.86 & 0.77 & 0.67 & 0.81 & 0.55 & 0.77 & 1.25 & 1.11 & 1.2 \\
\hline $\begin{array}{l}\text { Hemoglobin } \\
(\mathrm{g} / \mathrm{dL})\end{array}$ & $12-15.5$ & 7.2 & 8.2 & 7.6 & 6.9 & 6.9 & 8 & 7 & 7.6 & 6,6 & 7.1 & 8.4 & 8.6 & 10.4 & 10.5 \\
\hline $\begin{array}{l}\text { Platelet count } \\
\left(10^{3} / \mathrm{mL}\right)\end{array}$ & $150-450$ & 38 & 42 & 33 & 45 & 33 & 27 & 23 & 23 & 73 & 145 & 262 & 334 & 157 & 136 \\
\hline $\begin{array}{l}\text { C-reactive protein } \\
\text { (mg/L) }\end{array}$ & $0-5$ & 90.3 & 109 & 68.3 & 184 & 143 & 189 & 225 & 326 & 199 & 221 & 39.2 & NA & 3.14 & 11.4 \\
\hline $\begin{array}{l}\text { Procalcitonin } \\
(\mathrm{ng} / \mathrm{mL})\end{array}$ & $0-0.5$ & NA & NA & NA & NA & 0.72 & NA & NA & 2.18 & NA & 1.3 & NA & NA & NA & NA \\
\hline $\begin{array}{l}\text { Troponin } \\
\text { (pg/mL) }\end{array}$ & $3-14$ & 15.41 & NA & NA & 14.52 & 12.18 & NA & 13.11 & 13.51 & 7.82 & 4.77 & NA & NA & 6.91 & $<3$ \\
\hline $\begin{array}{l}\text { Creatinine } \\
\text { (mg/dL) }\end{array}$ & $0.5-0.9$ & 0.76 & 0.43 & 0.41 & 0.46 & 0.36 & 0.48 & 0.4 & 0.54 & 0.54 & 0.32 & NA & NA & 0.31 & 0.35 \\
\hline $\begin{array}{l}\text { Aspartate } \\
\text { transaminase } \\
\text { (units/L) }\end{array}$ & $0-32$ & 36 & 29 & 25 & 16 & 14 & 15 & 16 & 15 & 21 & 32 & NA & NA & 27 & 19 \\
\hline $\begin{array}{l}\text { Alanine } \\
\text { transaminase } \\
\text { (units/L) }\end{array}$ & $5-33$ & 22 & 22 & 17 & 9 & 7 & 8 & 8 & 6 & 5 & 10 & NA & NA & 11 & 14 \\
\hline $\begin{array}{l}\text { Lactate } \\
\text { dehydrogenase } \\
\text { (units/L) }\end{array}$ & $135-225$ & 1859 & 1753 & 1487 & 1189 & 961 & 949 & 866 & 734 & 547 & NA & NA & NA & 260 & 221 \\
\hline $\begin{array}{l}\text { Prothrombin time } \\
\text { (sec) }\end{array}$ & $10.5-14.5$ & 11.6 & 10.5 & 11.1 & 11.8 & 12.9 & 12.4 & NA & 12.6 & NA & 13.5 & NA & 13.6 & NA & NA \\
\hline $\begin{array}{l}\text { Ferritin } \\
(\mathrm{ng} / \mathrm{mL})\end{array}$ & $13-150$ & NA & NA & NA & 1154 & 1042 & 1692 & 1853 & 2332 & 3133 & 2000 & NA & 1851 & 1549 & 1246 \\
\hline Fibrinogen & $180-350$ & 304 & 319 & 262 & 549 & NA & 668 & NA & NA & 305 & NA & NA & NA & 319 & 309 \\
\hline $\begin{array}{l}\text { D-dimers } \\
(\mu \mathrm{g} / \mathrm{mL})\end{array}$ & $0-0.55$ & 10.12 & NA & 10.07 & 13.45 & 3.58 & 5.4 & 5.42 & 2.31 & 5.47 & 5.66 & NA & 5.04 & 1.69 & 1.09 \\
\hline
\end{tabular}

\section{Discussion}

There are some studies although few reported that pregnant women with COVID-19 pneumonia showed a similar pattern of clinical characteristics to non-pregnant adult patients ${ }^{(7,3)}$. Common symptoms at the onset of COVID-19 pneumonia for these women included fever and cough, whereas less common symptoms were myalgia, malaise, sore throat, diarrhoea, and shortness of breath. In a recent study conducted by Chen et al., nine women diagnosed with COVID-19 during the third trimester of pregnancy. In this small series, the clinical presentation was similar to that seen in nonpregnant adults, with fever in seven, cough in four, myalgia in three, and sore throat and malaise each in two women. Five women had lymphopenia. All patients had pneumonia, but none of them required mechanical ventilation, and none of them died. All women had a cesarean delivery $^{(10)}$. Our patient applied to the emergency 
room with shortness of breath, weakness and sore throat. In addition, the patient had deep anemia and thrombocytopenia increased ALT and AST concentrations at the time of admission. However, none of these symptoms was present in every patient, nor were the symptoms specific to pregnant women with COVID-19 pneumonia. These abnormalities in laboratory values can be observed in other pregnancy-related complications like our patient. Preeclampsia was observed in our patient with findings related to infection and underwent a caesarean section.

COVID-19 disease has prominent manifestations from the hematopoietic system and is often associated with a major blood hypercoagulability. Lymphopenia is a cardinal laboratory finding with prognostic potential. Biomarkers, such as high serum procalcitonin, $\mathrm{LDH}, \mathrm{CRP}$, fibrinogen and ferritin, have emerged as poor prognostic factors. Elevated D-dimer levels are consistently reported, whereas their gradual increase during disease course is particularly associated with disease worsening ${ }^{(9)}$. Our patient applied to the emergency room with deep anemia and thrombocytopenia, although there was no lymphopenia at admission. However, she developed lymphopenia during her clinical follow-up. Increased serum procalcitonin, LDH, CRP, fibrinogen and ferritin values were observed during the treatment process. The treatment effectiveness was monitored with the change in these values. Careful evaluation of laboratory indices at baseline and during the disease course can assist clinicians in formulating a tailored treatment approach and promptly provide intensive care to those who are in greater need.

The finding of a respiratory virus does not necessarily mean that the patient has only a viral infection. Occurrences of viral respiratory tract infections have been associated with increased risk of bacterial coinfections ${ }^{(11)}$. The rate of concurrent severe bacterial infections with viral illness in COVID-19 patients is appreciable. However, seconder infections as a result of prolonged hospital exposure may affect the severity of COVID-19 illness and increase mortality. A retrospective study from China showed that in the current Covid-19 pandemic, one in seven patients hospitalized with COVID-19 has attained a dangerous secondary bacterial infection, where almost $50 \%$ non-survivors experienced a secondary infection ${ }^{(12)}$. Our patient also developed a secondary surgical site infection during hospitalization. Therefore, the patient's length of stay was extended and broad-spectrum antibiotherapy and surgical treatment were required. There was guidance in the treatment management in abnormal hematological parameters. The patient was successfully followed-up and successfully treated by the department of infectious diseases, internal medicine, obstetrics, hematology and rheumatology with a multidisciplinary approach.

\section{References}

1. Chan JF, Yuan S, Kok KH, To KK, Chu H, Yang J, Xing F, Liu J, Yip CC, Poon RW, Tsoi HW, Lo SK, Chan KH, et al. A familial cluster of pneumonia associated with the 2019 novel coronavirus indicating person-to-person transmission: a study of a family cluster. Lancet. 2020; 395:514-23. https://doi.org/10.1016/S01406736(20)30154-9 PMID:31986261

2. Cheng ZJ, Shan J. 2019 Novel coronavirus: where we are and what we know. Infection. 2020; 48:155-163. https://doi.org/10.1007/s15010-020-01401y PMID:32072569

3. Li Q, Guan X, Wu P, Wang X, Zhou L, Tong Y, Ren R, Leung KS, Lau EH, Wong JY, Xing X, Xiang N, Wu Y, et al. Early Transmission Dynamics in Wuhan, China, of Novel Coronavirus-Infected Pneumonia. N Engl J Med. 2020; 382:1199-207. https://doi.org/10.1056/NEJMoa2001316 PMID:31995857

4. Phan LT, Nguyen TV, Luong QC, Nguyen TV, Nguyen HT, Le HQ, Nguyen TT, Cao TM, Pham QD. Importation and Human- 
to-Human Transmission of a Novel Coronavirus in Vietnam. N Engl J Med. 2020; 382:872-74. https://doi.org/10.1056/NEJMc2001272 PMID:31991079

5. Zhu N, Zhang D, Wang W, Li X, Yang B, Song J, Zhao X, Huang B, Shi W, Lu R, Niu P, Zhan F, Ma X, et al, and China Novel Coronavirus Investigating and Research Team. A Novel Coronavirus from Patients with Pneumonia in China, 2019. N Engl J Med. 2020; 382:727-33. https://doi.org/10.1056/NEJMoa2001017 PMID: 31978945

6. WHO. Coronavirus disease (COVID-19) pandemic.

2020. https://www.who.int/emergencies/diseases/ novel-corona virus-2019 (accessed16/4/2020).

7. Huang C, Wang Y, Li X, et al. Clinical features of patients infected with 2019 novel coronavirus in Wuhan, China. Lancet 2020; published online Jan 24. https://doi.org/10.1016/S0140-

6736(20)30183-5.

8. C. Rothe, M. Schunk, P. Sothmann, G. Bretzel, G. Froeschl, C. Wallrauch, et al., Transmission of 2019-nCoV infection from an asymptomatic contact in Germany, N. Engl. J. Med. 382 (2020) 970-971, https://doi.org/10.1056/nejmc2001468.

9. Terpos E, Stathopoulos IN, Elalamy I, et al. Hematological findings and complications of COVID-19, Am J Hematol. 2020;1-14. https://doi.org/10.1002/ajh.25829.

10. Chen H, Guo J, Wang C, et al. Clinical characteristics and intrauterine vertical transmission potential of COVID-19 infection in nine pregnant women: a retrospective review of medical records. Lancet 2020. published online Feb. 12, 2020.
11. Beadling, C. \& Slifka, M.K.(2004). How do viral infections predispose patients to bacterial infections? Curr Opin Infect Dis, 17,3,185-191.

12. Zhou F, Yu T, Du R, et al . (2020). Clinical course and risk factors for mortality of adult inpatients with COVID-19 in Wuhan, China: a retrospective cohort study. 2020 Mar 28; Lancet, 395(10229),1054- 1062. doi: 10.1016/S0140-6736(20)30566-3. 